\title{
Sitting-height measures are related to body mass index and blood pressure levels in children
}

\author{
Correlações entre altura sentada, índice de massa \\ corpórea e pressão arterial em crianças
}

Daniele Gasparini Marcato', Jéssica Dutra Sampaio', Eduardo Roberty Badiani Alves' ${ }^{1}$ Julyanna Silva Araujo de Jesus' ${ }^{1}$, Jeanne Teixeira Bessa

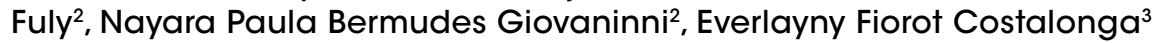

\footnotetext{
${ }^{1}$ Medical School, Universidade de Vila Velha (UVV), Vila Velha, ES, Brazil 2 Pharmacy School, UW, Vila Velha, ES, Brazil ${ }^{3}$ Universidade de São Paulo (USP), Universidade Federal do Espírito Santo (Ufes), UV, Vila Velha, ES, Brazil

Daniele Gasparini Marcato and Jéssica Dutra Sampaio have had similar contributions
}

\begin{abstract}
Objective: Sitting height (SH) is an important parameter in the evaluation of children with growth and pubertal disorders. Besides this, it has been viewed as a biomarker of cardiovascular risk, which is increased in adults with relatively short legs. So, the aim of this study was to evaluate the relationship between body proportions and cardiovascular risk markers in children. Subjects and methods: Eight hundred and seventeen children aged 6-13 years were evaluated. Weight, height, sitting-height (SH), sitting-height/height $(\mathrm{SH} / \mathrm{H})$, body mass index (BMI) and blood pressure (BP) were assessed and converted to standard deviation scores (SDS) for age and sex. Statistical analyses were performed. Results: There was a positive association of BMI SDS with SH and SH/H SDS $(p<0.001)$. Overweight children showed SH 0.8 SDS superior to eutrophic children $(p<0.001)$. SH SDS was also directly related to BP SDS, but this association was not independent of the association between obesity and BP when assessed by multiple regression analyzes. Conclusion: Measures of $\mathrm{SH}$ are strongly associated with $\mathrm{BMI}$ and $\mathrm{BP}$ in children, although the association between $\mathrm{SH}$ and BP is probably dependent on the association of both those variables with BMI. This is (an) important information for correct interpretation of SH values in children. Arq Bras Endocrinol Metab. 2014;58(8):802-6
\end{abstract}

\section{Keywords}

Sitting height; obesity; hypertension; children

\section{RESUMO}

Correspondence to: Everlayny Fiorot Costalonga Universidade de Vila Velha,

Coordenação do Curso de Medicina, Policlínica, $3^{\circ}$ andar

Av. Comissário José Dantas de Melo, 21

29102-920 - Vila Velha, ES, Brazil everlayny@gmail.com

Received on Feb/28/2014 Accepted on May/30/2014 DOI: 10.1590/0004-2730000003312
Objetivo: A altura sentada (sitting height, SH) é um importante parâmetro na avaliação de crianças com distúrbios do crescimento e da puberdade. Além disso, tem sido vista como um marcador de risco cardiovascular, aumentado em adultos com pernas relativamente curtas. $\mathrm{O}$ objetivo deste estudo foi avaliar a relação entre proporções corporais e marcadores de risco cardiovascular em crianças. Sujeitos e métodos: Oitocentas e dezessete crianças de 6 a 13 anos foram avaliadas. Peso, altura, altura sentada $(\mathrm{SH})$, altura sentada/total $(\mathrm{SH} / \mathrm{H})$, índice de massa corpórea (IMC) e pressão arterial (PA) foram avaliados e convertidos em Z escores ajustados para sexo e idade. Análises estatísticas apropriadas foram desenvolvidas. Resultados: Houve associação positiva do Z-IMC com o SH e o SH/H $(p<0,001)$. Crianças com excesso de peso demonstraram Z-SH 0,8 superior ao de crianças eutróficas $(p<0,001)$. O Z-SH também apresentou correlação direta com o Z-PA, mas essa associação não foi independente da relação entre IMC e PA quando analisada por meio de regressão linear múltipla. Conclusão: Medidas de SH são fortemente associadas ao IMC e PA em crianças, embora a associação entre SH e PA seja provavelmente dependente da associação de ambas as variáveis com o IMC. Essa é uma importante informação para a correta interpretação dos valores de SH em crianças. Arq Bras Endocrinol Metab. 2014;58(8):802-6

\section{Descritores}

Altura sentada; obesidade; hipertensão; crianças 


\section{INTRODUCTION}

$\mathrm{T}$ he decomposition of statural growth in terms of proportions between upper and lower segments is one of the most common ways of analysis of growth proportions. It has been used as an important auxological parameter, essential in the clinical evaluation of children with growth and/or pubertal disturbances (1-4).

The most frequently used method to represent growth proportions is the ratio between sitting height $(\mathrm{SH})$ and total height $(\mathrm{H})$, named sitting height/ height $(\mathrm{SH} / \mathrm{H})$. It reflects the proportion of someone's height which is attributed to the head and the trunk, in relation to members. Thus, individuals with relatively long members have lower sitting height/height, while individuals with relatively short members have higher sitting height/height measures $(1,2)$.

In clinical practice, the assessment of growth proportions is a valuable tool to detect diseases which affect growth of trunk and members in a disproportional manner, such as achondroplasias, Turner syndrome, hypothyroidism and Leri-Weill discondrosteosis. In some children with idiopathic short stature, for instance, the presence of high sitting height/height ratios can be the only sign of clinical suspicions of SHOX gene haploinsufficiency, a diagnosis which influences their prognosis, treatment and genetic counseling (2-6). Therefore, the accurate interpretation of values of $\mathrm{SH}$ and $\mathrm{SH} / \mathrm{H}$ are fundamental in the management of those children.

In adults, relatively long members have been associated with increased risk of cancer (2), while relatively short members have been associated to higher rates of diabetes, dyslipidemia $(8,9)$, hypertension $(9,10)$ and adverse cardiovascular outcomes $(3,11)$. In children, few studies were directed to those associations.

In 2007, a study involving exclusively female children and adolescents between 9 and 16-years-old suggested that short legs were associated to increased blood pressure levels (12). To date, no studies have investigated that hypothesis in Brazilian children.

Thus, the aims of the study were to evaluate growth proportions, represented by sitting height/height, in Brazilian children of both genders, analyzing its associations with cardiovascular risk factors, such as excess of weight, waist circumference and blood pressure levels.

\section{SUBJECTS AND METHODS}

Male and female children between 6 and 13 years old, from public primary schools located in Vila Velha, ES, were assessed. The study was approved by the Ethics Committee of the Institution and the authors complied with the World Medical Association Declaration of Helsinki concerning the ethical conduct of research involving human subjects. Only children whose parents or tutors agreed with their participation through written informed consent were included. Total height, sitting height, weight, waist circumference and blood pressure levels were evaluated according to the following described protocols.

Height measurements were made through a stadiometer graduated from 20 to $200 \mathrm{~cm}$, with precision scales of $0.1 \mathrm{~cm}$. The average of three consecutive measurements was considered. The children were evaluated in ortostasis, without shoes, with hip and shoulders perpendicular to the central axis of the body, firmly supported heels, close and extended knees, relaxed arms and their heads in the Frankfurt plane. The sitting height was obtained adapting a removable box $(60 \mathrm{~cm})$ to the stadiometer, where the child was sat with the trunk erect and the head in the Frankfurt plane.

The weight was measured on a digital scale with a capacity of $150 \mathrm{~kg}$ and precision of $50 \mathrm{~g}$. The body mass index (BMI), defined as weight in kilograms divided by height in meters squared, was calculated and converted to BMI standard deviation scores (SDS), adjusted by age and sex. It was used to evaluate the children's nutritional status, according to distribution of percentiles and cutoffs proposed by the Center of Disease Control (CDC), which considers overweight a BMI $\geq$ the $85^{\text {th }}$ percentile and $<$ the $95^{\text {th }}$ percentile and as obesity, a BMI $\geq$ the $95^{\text {th }}$ percentile (7).

The waist circumference was measured with the child standing, at the end of the expiration, at midpoint between the last costal arch and the anterosuperior iliac crest, using an inelastic measuring tape in the horizontal position, as recommended by the World Health Organization (WHO).

The blood pressure (BP) assessment was performed by auscultation, using a stethoscope, a previously calibrated aneroid sphygmomanometer, and the adequate cuff selected according to the arm circumference. The midpoint of the compressive part of the cuff was placed on the brachial artery and the systolic blood pressure (SBP), as well as the diastolic blood pressure (DBP) were measured. The procedure was repeated two more times, with at least three minute intervals between them. The mean value of the three 
measurements was compared to the reference values from The Fourth Report on the Diagnosis, Evaluation and Treatment of High Blood Pressure in Children and Adolescents of the National High Blood Pressure Education Program (NHBPEP). Children with blood pressure levels in the range of hypertension (SBP or DBP $\geq$ the $95^{\text {th }}$ percentile for sex, age and height) or pre-hypertension (SBP or DBP $\geq$ the $90^{\text {th }}$ percentile for sex, age and height), as defined by the NHBPEP report, were considered to have high blood pressure levels. The mean value of three blood pressure measurements was also converted in SDS in order to permit some of the statistical analysis (13).

The data were entered in an Excel spreadsheet. The Growth Analyser 3.5 software was used to convert the values of height, weight, BMI, waist circumference, sitting height and sitting height into standard deviation scores adjusted for sex and age. The SigmaStat for Windows (3.5, SPSS, Inc., San Rafael, CA) software was used for statistical calculations. The level of significance was set at 0.05 for all statistical tests.

\section{RESULTS}

A total of 817 children were evaluated, $51 \%(n=417)$ boys and $49 \%(n=400)$ girls, with, on average, $8.8 \pm$ 1.6 years. Obesity was observed in $11 \%$, overweight in $13 \%$ and underweight in $4 \%$, while $72 \%$ of them presented adequate body mass index for sex and age. Blood pressure levels were elevated in $7 \%$ of children, with $4 \%$ of children showing levels in the range of hypertension, and $3 \%$ in the range of pre-hypertension. Only $2 \%$ of children had sitting/height below $-2,0$ SDS, and all of them showed adequate BMI SDS. No one child reached sitting height/height values above +2 SDS.

A direct relationship between growth proportions and nutritional class was observed. Children with excess of weight (obesity or overweight) had higher sitting height $(\mathrm{SH})$ measures than children without excess of weight, with SH SDS, on average, 0.8 superior $(\mathrm{p}<$ 0.001 ; Table 1). Regression analysis showed that the BMI SDS had a direct and linear influence on both SH SDS $\left(p<0.001, \mathrm{R}^{2}=0.22\right)$ and SH $/ \mathrm{H} \mathrm{SDS}(p<0.001$, $\left.\mathrm{R}^{2}=0.02\right)$ (Table 1; Figure 1). Waist circumference was also directly related to SH SDS $(p<0.001)$ and SH $/ \mathrm{H}$ SDS $(p=0.05)$.

The association was also direct and linear for $\mathrm{SH}$ SDS and BP levels SDS, both systolic (SBP) $(p<0.001)$ and diastolic (DBP) $(p<0.001)$. However, when adjusted for total height, by $\mathrm{SH} / \mathrm{H}$ SDS, that association was not statistically significant. Furthermore, multiple linear regression analysis demonstrated that the influence of SH SDS on the BP SDS was not independent of BMI SDS $(p=0.7)$. Those analyses showed that the BMI SDS was the main predictor of BP levels, both systolic $\left(p<0.001 ; \mathrm{R}^{2}=0.06\right)$ and diastolic $(p<0.001$; $\left.\mathrm{R}^{2}=0.04\right)$ (Table 2; Figure 2) in those children.

Table 1. Comparison between children with and without excess of weight, regarding body proportions

\begin{tabular}{lccc}
\hline & $\begin{array}{c}\text { With excess of } \\
\text { weight }\end{array}$ & $\begin{array}{c}\text { Without excess } \\
\text { of weight }\end{array}$ & $\boldsymbol{P}$ \\
\hline Sitting Height SDS* & $-0.1 \pm 0.8$ & $-0.9 \pm 0.8$ & $<0.001$ \\
Sitting Height / Height SDS* & $-0.1 \pm 0.8$ & $-0.3 \pm 0.8$ & 0.03 \\
\hline
\end{tabular}

* Mean \pm standard deviation.
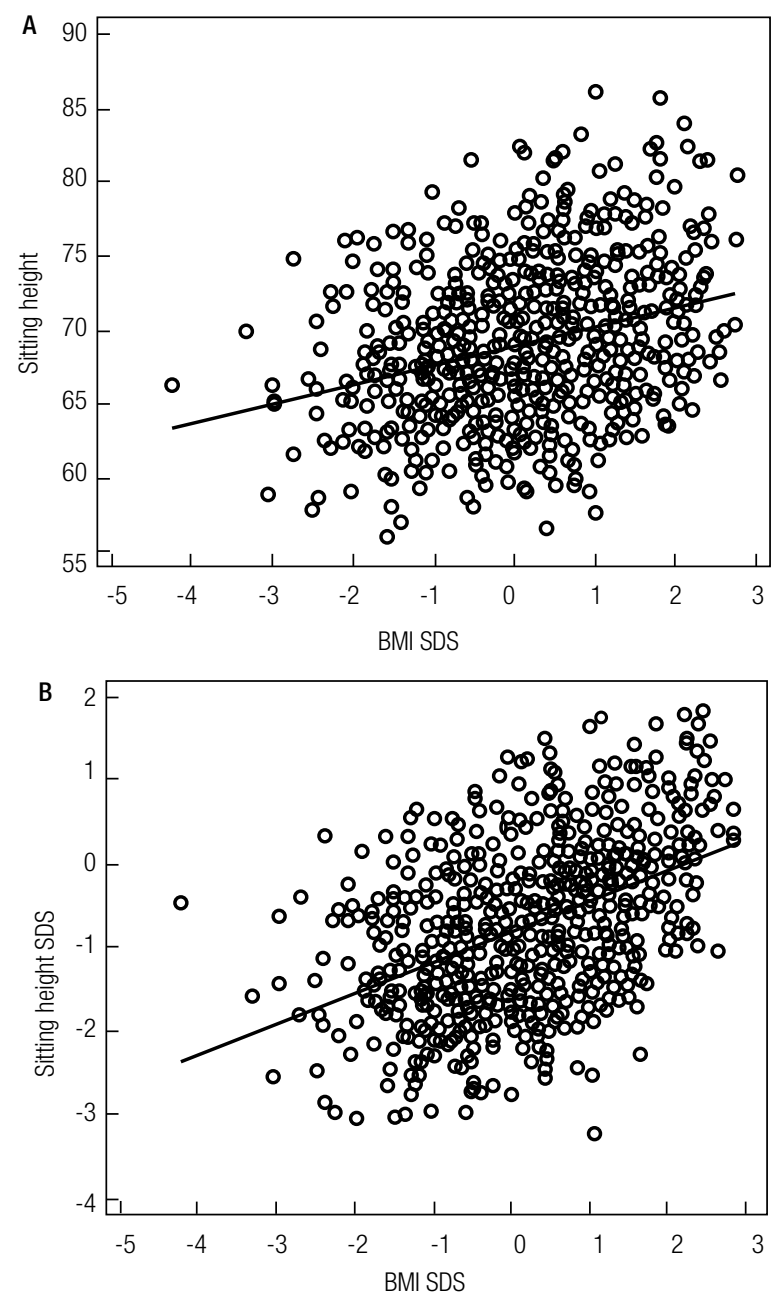

Figure 1. Linear regression between body mass index (BMI) standard deviation scores (SDS) and sitting height (SH) $(\mathbf{A})$ or sitting height SDS (B). 
Table 2. Systolic and diastolic blood pressure (BP) SDS in children with and without excess of weight

\begin{tabular}{lcc}
\hline & Systolic BP SDS & Diastolic BP SDS \\
\hline WITH escess of weight $^{\star}$ & $-0.1 \pm 0.8$ & $0.4 \pm 0.7$ \\
WITHOUT excess of weight* $^{\star}$ & $-0.5 \pm 0.8$ & $0.1 \pm 0.7$ \\
$P$ & $<0.001$ & $<0.001$ \\
\hline
\end{tabular}

${ }^{*}$ Mean \pm standard deviation.
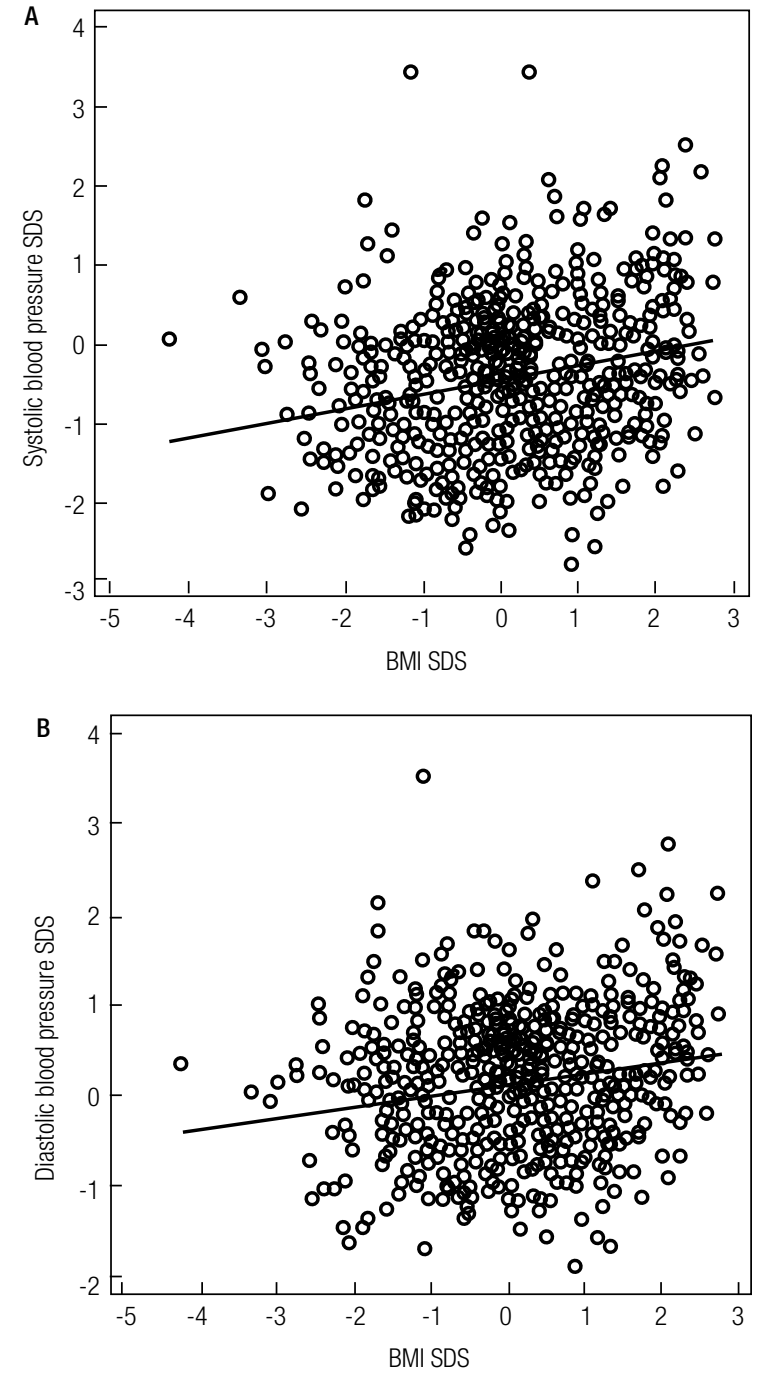

Figure 2. Linear regression between body mass index (BMI) standard deviation scores (SDS) and systolic (A) or diastolic (B) blood pressure SDS.

\section{DISCUSSION}

This is the first study analyzing the association between growth proportions and cardio-metabolic risk markers (obesity and hypertension) in Brazilian children.

Until recently, the risk of high blood pressure in children was neglected in pediatric clinical practice. Currently, growing evidence shows that hypertension in adults has antecedents in childhood (8), and that risk detection in that period can impact the occurrence of adverse events in young adults (9-12). The first highlight of this study is the prevalence of $7 \%$ of children with high blood pressure levels, showing that hypertension is not rare in that age.

Although one previous study has suggested a direct association between growth proportions and blood pressure levels in children, in this sample, the association between $\mathrm{SH}$ and $\mathrm{BP}$ was not independent of the degree of excess of weight, which influenced both, sitting height and blood pressure. This possible confounding bias was not evaluated in that previous study, which was also restricted to females and based on a single blood pressure measurement, without adjustment to age and height (7).

It is important to note the strong association observed between excess of weight and sitting height, as demonstrated by direct and linear association between BMI, SDS and SH SDS. That relationship was also evident when $\mathrm{SH}$ was adjusted to height $(\mathrm{SH} / \mathrm{H})$, showing that it is not solely due to the fact that obese children are taller. In addition, the possibility of a bias caused by the accumulation of fat in the hip region was low, owing to the fact that the association was independent of hip circumference on multiple regression analyses.

We consider that the correlation between relatively long trunk and the presence of excess of weight could explain, at least in part, the previously described associations between cardiovascular risk and relatively short legs. However, we cannot exclude the possibility that both associations are linked to a common pathophysiological mechanism, such as the insulin resistance, which has been related to hasty closing of long bones epiphyses. Regardless of the mechanisms involved in that association, it is important for health professionals to be aware of that. They need to be alert to the fact that children who are overweight or obese tend to have relatively long trunk when compared to members, which may interfere in the interpretation of $\mathrm{SH}$ and $\mathrm{SH} / \mathrm{H}$ values. The exact cause of that association and the possible relationship with other cardiovascular and metabolic risk factors need to be further evaluated.

Acknowledgements: to children and their parents, who kindly accepted to participate. To school professionals, whose collaboration was essential to the development of our research.

Financial support: this work was supported with grants by Fundação Nacional de Desenvolvimento do Ensino Superior Particular (Funadesp) to Everlayny Fiorot Costalonga, by Fundação de Amparo à Pesquisa do Espírito Santo (Fapes) to Jéssica Dutra Sampaio 
and Nayara Paula Bermudes Giovaninni and by Universidade de Vila Velha to Eduardo Roberty Badiani Alves and Julyanna Silva Araújo de Jesus.

Disclosure: no potential conflict of interest relevant to this article was reported.

\section{REFERENCES}

1. Bogin B, Varela-Silva MI. Fatness biases the use of estimated leg length as an epidemiological marker for adults in the NHANES III sample. Int J Epidemiol. 2008;37(1):201-9.

2. Gerver WJM, Bruin R. Body Proportions in Children. Dutch Growth Foundation, Growth Analyser 3, 2007.

3. Jorge AA, Nishi MY, Funari MF, Souza SC, Arnhold IJ, Mendonca BB. [Short stature caused by SHOX gene haploinsufficiency: from diagnosis to treatment]. Arq Bras Endocrinol Metabol. 2008;52(5):765-73.

4. Binder G, Ranke MB, Martin DD. Auxology is a valuable instrument for the clinical diagnosis of SHOX haploinsufficiency in school-age children with unexplained short stature. J Clin Endocrinol Metab. 2003;88(10):4891-6.

5. Fredriks AM, van Buuren S, van Heel WJ, Dijkman-Neerincx RH, Verloove-Vanhorick SP, Wit JM. Nationwide age references for sitting height, leg length, and sitting height/height ratio, and their diagnostic value for disproportionate growth disorders. Arch Dis Child. 2005;90(8):807-12.
6. Malaquias AC, Scalco RC, Fontenele EG, Costalonga EF, Baldin $A D, B r a z A F$, et al.The sitting height/height ratio for age in healthy and short individuals and its potential role in selecting short children for SHOX analysis. Horm Res Paediatr. 2013;80(6):449-56.

7. August GP, Caprio S, Fennoy I, Freemark M, Kaufman FR, Lustig $\mathrm{RH}$, et al. Prevention and treatment of pediatric obesity: an endocrine society clinical practice guideline based on expert opinion. J Clin Endocrinol Metab. 2008;93(12):4576-99.

8. Lauer RM, Clarke WR. Childhood risk factors for high adult blood pressure: the Muscatine Study. Pediatrics. 1989;84(4):633-41.

9. Bergmann GG, Gaya A, Halpern R, Bergmann ML, Rech RR, Constanzi $\mathrm{CB}$, et al. [Body mass index to the cardiovascular disease risk screening in infancy]. Arq Bras Endocrinol Metabol. 2011;55(2):114-20.

10. Costanzi CB, Halpern R, Rech RR, Bergmann ML, Alli LR, Mattos AP. Associated factors in high blood pressure among schoolchildren in a middle size city, southern Brazil. J Pediatr (Rio J). 2009;85(4):335-40.

11. Gomes Bda M, Alves JG. [Prevalence of high blood pressure and associated factors in students from public schools in Greater Metropolitan Recife, Pernambuco State, Brazil, 2006]. Cad Saude Publica. 2009;25(2):375-81.

12. Molina Mdel C, Faria CP, Montero MP, Cade NV, Mill JG. [Cardiovascular risk factors in 7-to-10-year-old children in Vitoria, Espirito Santo State, Brazil]. Cad Saude Publica. 2010;26(5):909-17.

13. National High Blood Pressure Education Program Working Group on High Blood Pressure in Children and Adolescents. The fourth report on the diagnosis, evaluation, and treatment of high blood pressure in children and adolescents. Pediatrics. 2004;114/2 Suppl 4th Report):555-76. 